\title{
Del cromo al origen de la aventi en la narrativa de Juan Marsé
}

\section{From sticker to the origin of the aventi in the narrative of Juan Marsé}

Yolanda Pérez Sinusía [yopesi@hotmail.com]

Escuela Oficial de Idiomas de la Comunidad de Madrid, España

\section{RESUMEN:}

La escritura de Juan Marsé se caracteriza por un fuerte componente visual que se deriva principalmente del hecho de que el autor parte de imágenes, no de ideas, a la hora de concebir su creación literaria. En este artículo pretendemos indagar sobre el origen de esta visualidad a partir de la utilización por parte del escritor de cromos o imágenes que ahondan en su infancia a la aparición de la aventi o las aventuras que oralmente se cuentan los personajes de sus obras, donde se mezclan apariencia y realidad. Para ello, nos centraremos en tres de sus primeras novelas: Últimas tardes con Teresa (1966); La oscura historia de la prima Montse (1970) y Si te dicen que caí (1973).

\section{Palabras clave:}

Imagen; visualidad; narrativa; cine

\begin{abstract}
:
The writing style of Juan Marsé is characterized by a strong visual component which principally derives from the fact that the author begins with images, not ideas, when he conceives his literary creation. The aim of this paper is to investigate the origin of this visual component in his work from the use of stickers or images which deepens in his childhood to the appearance of the aventi or adventures that the characters of his novels are told orally to each other, where appearance and reality mix. To that end, we focus on his first three novels: Últimas tardes con Teresa (1966); La oscura historia de la prima Montse (1970) and Si te dicen que caí (1973).
\end{abstract}

\section{KEYWORDS:}

Image; visual component; narrative; cinema

RECIBIDO 2015-08-21; ACEPTADO 2015-12-15 


\section{Introducción: del cromo a la aventi}

En varias ocasiones el escritor Juan Marsé (Barcelona, 1933) ha reiterado que concibe sus novelas a partir de imágenes, no de ideas o palabras, que después ordena de manera que den lugar a una historia cuyo objetivo sea hacer ver a sus lectores lo que narra ${ }^{1}$. Así, el escritor catalán confirma que a la hora de escribir una novela busca imágenes que acostumbra a comparar con la manipulación de una colección de cromos (Freixas 1984: 52), idea que se ha reiterado incluso en algunos volúmenes monográficos centrados en el conjunto de la obra del escritor como los coordinados por López de Abiada (2002), Romea (2005), Rodríguez (2008), Bonet (2009 y 2010) o en la biografía del autor realizada por Cuenca (2015).

Samuel Amell fue uno de los primeros críticos literarios que, por un lado, comprobó cómo el escritor daba vida a las imágenes iniciales forjadas en su mente que servían de motor para la creación de sus novelas y que, por otro, señaló la importancia de la formación visual con la que contaba Marsé desde niño, por ejemplo, con su afición por las colecciones de cromos, las lecturas de tebeos y el visionado de las películas que se proyectaban en las salas de su barrio barcelonés (1984: 15-16). En consecuencia, tanto su forma de plantearse el proceso creativo como el germen de su formación visual son de vital importancia en el desarrollo de su obra. De hecho, ya es un lugar común decir que su narrativa no ha dejado de acusar la importancia del séptimo arte como motor para su creación, línea de investigación planteada en estudios monográficos como los de Castellani (2003) y Seguin (2004) o por parte de investigadores como Marí (2003) y Kim (2006).

Esta característica, junto con una temática (la infancia/adolescencia, la recuperación de la memoria, el doble); una época y un lugar (la posguerra española y Barcelona, en especial los barrios de Horta, el Carmelo, el Guinardó y la Salud); una tradición literaria (sobre todo la cervantina, con el juego entre realidad y ficción; la picaresca, con la aspiración de ascenso social de sus personajes; el folletín; el melodrama, con lo que conllevan de sentimentalidad, acción y suspense) y unos procedimientos específicos (la ironía, la parodia, el collage, la (des)mitificación, el voyeurismo y la aventi, que crea su particular colección de imágenes/cromos), conforman una estética muy concreta en sus novelas que abre nuevos caminos en la representación de la realidad a través de un ejercicio continuo de hacer ver con palabras al lector/espectador: la presencia del cine en su obra resulta prueba fehaciente de ello. En este artículo nos centraremos en el origen de esta visualidad en la narrativa de Juan Marsé.

Hasta la publicación de la novela La oscura historia de la prima Montse (1970), podemos señalar que los personajes de Juan Marsé desean escapar de su entorno, ya sea por su situación social o por problemas de identidad, ya sea por una memoria histórica que no les satisface y, para ello, forjan en su pensamiento una serie de imágenes o cromos, que recrean un mundo idílico, lleno de luz y color que contrasta fuertemente con la realidad gris de los años treinta al cincuenta del siglo XX en la que están inmersos la mayoría de los protagonistas de sus novelas. Estas imágenes o cromos constituyen un producto de la fantasía de unos personajes que intentan compensar de este modo su discrepancia con la realidad que les has tocado vivir.

$1 \quad$ Véanse a este respecto a Ana María Moix (1973: 122); Montserrat Roig (1975: 88); Samuel Amell (1984: 14 y 26); Juan Marsé, Primera imagen, primer latido (1990); Balbina Samaniego (1993: 377). 
A partir de Si te dicen que caí (1973), estos cromos dejan de ser ilustraciones para comenzar a cobrar movimiento y narrativizarse, con unos protagonistas que colorean la realidad a su gusto. Así, Marsé crea las aventis (término inventado por el autor, reducción de la palabra aventuras), historias orales que se cuentan entre los niños y adolescentes en la época de la posguerra -casi todos tienen en común la ausencia de un padre mitificado- $y$, al igual que en la vieja tradición de Las mil y una noches, el hecho de narrarlas ayuda a prolongar, si no la existencia de estos trinxas o niños de la posguerra, sí a hacerla mucho más amena evadiéndose de una realidad que no les gusta.

Las aventis se originan en un hecho que supuestamente ha sucedido y presentan la realidad de una manera proteica, ambigua y confusa. Los niños tratan de hacer ver a su auditorio las historias que narran a partir de elementos que proceden del cine tanto en su forma de narrar, como en su temática, en su manera de describir a sus personajes, en la utilización de géneros cinematográficos procedentes del cine del melodrama y del western, que forman parte mayoritariamente del cine creado en Hollywood y Gran Bretaña entre los años 30 y 40 del siglo XX y que alimentan el imaginario de sus protagonistas, a saber: Java, Sarnita (Si te dicen que caí), Néstor Julivert (Un día volveré), Juanito Marés (El amante bilingüe), Daniel y Nandu Forcat (El embrujo de Shanghai) o David Bartra (Rabos de lagartija).

Estos niños/adolescentes, y los ya adultos, se han formado en el visionado de las películas que se proyectan en las salas de cine de sus barrios -al igual que lo hizo Marsé de niño- y proyectan sus propias historias con personajes que imitan, copian o se parecen a los actores que ven en la pantalla, hasta tal punto que los nombres de los personajes de la ficción se mezclan con los de la película (Teresa Simmons, Jean Serrat) o incluso se llaman como ellos, por ejemplo, Charles Lagartón, en alusión al actor inglés Charles Laughton; o la Betibú, en referencia al personaje americano de dibujos animados, Betty Boop.

Los narradores consiguen con su capacidad de contar identificarse con una cámara de cine y convertir al oyente en espectador de estas historias. Las aventis y, en consecuencia, el cine, contribuyen a escapar de la realidad de esa España de posguerra, además de crear estereotipos que piden la complicidad con el lector dotado de una competencia cinematográfica o espectatorial. En la narrativa de Juan Marsé se crea el simulacro de estar viendo una película.

De este modo, las aventis cumplen distintos fines. En primer lugar, se pueden prolongar todo lo que se quiera con el fin de obtener dinero, quitar el hambre o encontrar el ascenso social (es el caso de Java con la señora Galán en Si te dicen que caí, que no deja de ser una prolongación del pícaro dentro de la tradición de la novela picaresca española). En segundo lugar, tratan de resolver hechos que sucedieron en el pasado con el retorno de un héroe mitificado que no se corresponde con el mito creado en las mentes de los niños y adolescentes (Un día volveré, 1982). Por último, mantienen la ilusión de todos aquellos niños huérfanos de padres a causa de las circunstancias políticas de España en los años de la posguerra, como en El embrujo de Shanghai (1993).

En El embrujo de Shanghai la aventi abandona Barcelona, el espacio habitual de esta narrativa, para viajar hasta Shanghai. La desilusión que ocasiona el choque con la realidad a los adolescentes protagonistas va a ser mucho mayor que en novelas anteriores. Además, cabe destacar que la aventi no está narrada por un niño sino por el ya adulto Nandu Forcat. 
Tras trazar este panorama general del paso del cromo a la aventi en la narrativa de Juan Marsé publicada desde los años 60 a los años 90, pasamos a analizar con más detalle el origen de esta visualidad que se produce en las obras de Últimas tardes con Teresa, La oscura historia de la prima Montse y Si te dicen que caí2.

\section{Los primeros cromos: Últimas tardes con Teresa y La oscura historia de la prima Montse}

A continuación, analizamos el paso del cromo a la aventi en la narrativa de Marsé, un paso en el que se aprecia una mayor presencia del cine y en el que los principales temas de su obra aparecen imbricados, a saber: el ascenso social (siguiendo una tradición picaresca); los difíciles límites entre la realidad y la apariencia (dentro de la tradición cervantina del engaño a los ojos); la memoria; la infancia y adolescencia de los niños de barrio que vivieron la posguerra en Barcelona y el doble.

Una de las constantes temáticas que se presentan en estos cromos y en la obra del escritor catalán en su conjunto es el deseo de ascenso social que alimenta el protagonista masculino a través del amor con personajes femeninos de la burguesía (Manolo Pijoaparte con Teresa en Últimas tardes con Teresa; Manuel con Montse y Paco Bodegas con Nuria en La oscura historia de la prima Montse $)^{3}$. El personaje masculino se dibuja en estos cromos como un héroe salvador inserto en un tiempo y paisaje idílico (el verano, la playa, la isla, etc.) que busca el reconocimiento de los padres de la chica burguesa para poder lograr un estatus social más elevado. Hay que decir que se trata de fantasías que no poseen un receptor, que forman parte del personaje, de su intimidad y no se comparten con otros personajes. De ahí que, en estos inicios, estas fantasías sean todavía cromos sin entidad propia.

En Últimas tardes con Teresa (1966), Manolo se configura desde el principio como un personaje que sueña con salir de su pobre condición social, lo que le lleva a disparar su imaginación con argumentos próximos a muchas de las novelas del siglo XIX. Para empezar, su nacimiento y origen social están maquillados por sus fantasías:

Manolo Reyes - puesto que tal es su verdadero nombre- era el segundo hijo de una hermosa mujer que durante años fregó los suelos del Palacio del marqués de Salvatierra, en Ronda [...] Una curiosa historia circulaba, según la cual su madre había tenido amores, a poco de enviudar, con un joven y melancólico inglés que fue huésped del marqués de Salvatierra durante unos meses. El niño nació en la fecha prevista según el malicioso cálculo de las malas lenguas. Pero Manolo arremetió siempre contra la pretendida autenticidad de esa historia [...] porque ponía en peligro, o por lo menos en entredicho, la existencia de otra que encendía mucho más su fantasía y que suponía para él la posibilidad de un origen social más noble: ser hijo del mismísimo marqués de Salvatierra (64-65).

2 Si bien las dos primeras novelas de Juan Marsé fueron Encerrados con un solo juguete (1960) y Esta cara de la luna (1962), en estos comienzos como novelista el escritor todavía no bebe de las fuentes de su infancia y el cine no aparece como evasión o como referente claro para la construcción de la trama (aunque sí que aparecen ya alusiones), por lo que centramos nuestro estudio desde Últimas tardes con Teresa, su tercera novela.

3 Véase para el tema del ascenso social el estudio de Bellón (2009). 
Es uno de los primeros cromos que tiene Manolo en su cabeza y que se relaciona con el deseo de ascenso social, entre otros objetivos, para paliar "el diario trato con el hambre" (66). Este hecho acerca a Manolo a héroes de la picaresca, en este caso a un pícaro que, para salir de una realidad que rechaza, recurre a su imaginación. Estas fantasías eran "sus únicos juguetes de la infancia [...], desde niño necesitó de la mentira lo mismo que el pan y el aire que respiraba” (66).

Este cromo desaparece rápidamente cuando una semana después conoce a la familia Moreau, que ha venido desde París para pasar sus vacaciones en Ronda. El matrimonio Moreau tiene una hija rubia de ojos azules y propone a Manolo irse con ellos a París. El niño se crea ilusiones, la nueva ciudad sería una vía de escape a su vida ${ }^{4}$, pero pronto sobreviene el choque con la realidad. Un día, los Moreau desaparecen sin decirle nada "pertenecían a esa clase de turistas que se sirven de la ilusión de los indígenas como un puente para alcanzar el mito, que luego, cuando ya no necesitan, destruyen tras de sí” (70). Desde entonces, a Manolo le queda el sabor amargo de lo que es rozar su ilusión sin conseguirla. Cuando Manolo se acostaba por las noches, lo primero que hacía era poner "en orden los personajes y el paisaje (profundos barrancos, llamas devoradoras, olas enfurecidas, terremotos, guerras) y vuelta a empezar" (91).

Manolo se traslada al barrio del Monte Carmelo en Barcelona en busca de trabajo, puesto que está allí su hermano empleado en un taller de bicicletas. No ha abandonado los cromos de su infancia, que siguen siendo sus aspiraciones de ascenso social a partir de la conquista de la chica rubia que, como ya hemos comentado, representa para el Pijoaparte (sobrenombre con el que se conoce también a Manolo Reyes) la inserción en la burguesía catalana. La nueva muchacha rubia ya no es la niña de los Moreau, sino Teresa Serrat, joven soñadora que quiere ver en Manolo a un obrero con conciencia de clase. Primero, Manolo seduce a Maruja, sin saber que ésta es tan sólo la criada de la casa de los Serrat. Un día ve a la muchacha en una embarcación junto a la playa, imagen que lleva al murciano a recrear una situación heroica, que tiene su origen en la infancia, como nos cuenta el narrador:

cruzó por la mente del murciano un fugaz espejismo, residuo de los sueños heroicos de la niñez: aquello era un terrible tifón, la muchacha estaba sin sentido en el fondo de la canoa, a merced de las olas enfurecidas y del viento mientras él luchaba a pecho descubierto, ya la tenía en sus brazos, desmayada, gimiendo, las ropas desgarradas, empapadas (¡despierte, señorita, despierte!), sangre en los muslos soleados y ese arañazo en un rubio seno, picadura de víbora, hay que sorber rápidamente el veneno, hay que curarla y encender un fuego, y quitarle las ropas mojadas para que no se enfríe, los dos envueltos en una manta, o mejor llevarla en volandas a la villa: el haber sabido respetar su desnudez abría una intimidad fulgurante que le daría acceso a las luminosas regiones hasta ahora prohibidas ("papà, et presento al meu salvador..." “Jove, no sé com agrair-li, segui, per favor, prengui una copeta...” y él, que se había herido en una pierna al trepar por las rocas con la bella en brazos (¿o era un esguince de haber jugado al tenis?) Cojeaba, cojeaba, cojeaba elegantemente, melancólicamente al avanzar ante la admiración y la expectación general hacia el cómodo sillón de la terraza, hacia una bien ganada paz y dignidad futuras (38).

4 Recordemos que Lavinia y Miguel Dot en Esta cara de la luna también quieren escapar a París, que representa el lugar donde los personajes podrán vivir libremente su amor (Lavinia es una mujer casada) y romperán con el contexto que les rodea. Quizás encontramos aquí una velada alusión a la película Casablanca de M. Curtiz (1942) y a la tan conocida frase "Siempre nos quedará París". 
En este fragmento encontramos un nuevo cromo de Manolo en el que sigue un esquema parecido a otras ocasiones: existe una muchacha envuelta en un peligro, en este caso un tifón (otras variantes que el personaje nos ofrece en su colección particular son un terremoto, un fuego), que sitúa a Manolo en posición de tener que rescatarla. El rescate le lleva a conocer al padre de la chica, de la burguesía catalana (ahí tenemos esas frases en catalán, lengua prohibida en el momento en que se publicó esta novela) y esto le permite el reconocimiento dentro de una clase a la que quiere pertenecer, presentándose como un ser honrado, ya que no ha tratado de aprovecharse de la chica en esa situación recreada. Así, Manolo teje sus cromos con elementos tomados de la novela popular, del cómic, del melodrama y de las películas de aventuras.

Más adelante, tras el accidente que ha llevado a Maruja a estar postrada en coma y en cama en un hospital, Manolo y Teresa pasan mucho tiempo juntos, lo que provoca que entre ellos surja algo más que una amistad. En una ocasión, la pareja va a la playa y el narrador nos cuenta de nuevo cómo la mente del Pijoaparte despliega su colección de cromos:

\begin{abstract}
Teresa Simmons en bikini corriendo por las playas de sus sueños, tendida sobre la arena, desperezándose bajo un cielo profundamente azul, el agua en su cintura y los brazos en alto (un áureo resplandor cobijado en sus axilas. Oscilando como los reflejos del agua bajo un puente) después nadando con formidable estilo, surgiendo de las olas espumosas [...] y finalmente viniendo desde la orilla hacia él como un bronce vivo [...] Jean Serrat sonriéndole a él, al tenebroso murciano, a ese elástico, gatuno, apostado montón de pretensiones y deseos y ardores inconfesables, y dolientes temores (la perderé, no puede ser, no es para mí, la perderé antes de que me deis tiempo a ser un catalán como vosotros, ¡caaaabrones! [...] Sólo por verla así, caminando despacio, semidesnuda y confiada, destacándose sobre un fondo de palmeras y selva inexplorada - ¿acaso no era la isla perdida este verano? - [... L La colección particular de satinados cromos se abrió en su mano como un rutilante abanico: él y ella perdidos en la dorada isla tropical solos, bronceados, hermosos [...], construyen una cabaña como un nido, corren por la infinita playa, comen cocos, pescan perlas y coral [...] (Teresa seguía avanzando perezosamente sobre la arena, hacia él). [...] Venía con una sonrisa luminosa y un coco prisionero entre su cintura y el brazo [...], y se dejó caer lentamente a su lado, doblando las hermosas rodillas, y soltó el coco [...] Teresa había soltado la pelota de goma (197-198).
\end{abstract}

El narrador nos sitúa la escenografía del nuevo cromo de Manolo en una isla desierta que representa lo idílico, el romanticismo, el único lugar en el que la pareja puede encontrarse libremente, sin trabas sociales. El Pijoaparte y Teresa se sitúan fuera de la realidad y el personaje masculino recrea el mito del paraíso eterno. El tiempo del idilio es el verano, el sol, el calor, como un paréntesis en las vidas que normalmente llevan durante el año “ ¿acaso no era la isla perdida este verano?"

Carmen Peña Ardid (2002) ha visto en este ejemplo una alusión a la película británica $L a$ isla perdida (The Blue Lagoon, F. Launder, 1949), protagonizada por Jean Simmons y Donald Huston donde encontramos una idílica historia de amores adolescentes en el paraíso de una isla desierta ${ }^{5}$. Esta referencia se puede complementar con una mezcla de imágenes de otras

5 La película es una adaptación de la novela de Henry Devere Stacpoole's. Se ha realizado algún remake como el de Brooke Shields en 1980. En La oscura historia de la prima Montse, Manuel, enviado por Montse, asiste a un cursillo de cristiandad en Vich y allí les hacen rellenar un formulario en el que menciona esta película: "Escriba dos aficiones de- 
películas norteamericanas tales como El hijo de la furia (Son of fury, J. Cromwell, 1942) en la que Benjamin Blake (el actor Tyrone Power) rompe con su pasado para hacerse rico recogiendo perlas en una isla y vivir junto a una de las bellas indígenas (Gene Tierney) en una cabaña; De aquí a la eternidad (From here to eternity, F. Zinnemann 1953) en la que se da rienda suelta a la pasión amorosa entre los actores Burt Lancaster y Debora Kerr. Ésta sale del mar en bañador y Lancaster queda prendado al verla. Incluso existe relación con Rebelión a bordo (Mutiny of the bounty, F. Lloyd 1935), en la que los tripulantes a bordo de un barco británico, la Mounty, llegan a una isla virgen tahitiana que sirve de huida por un tiempo de la dura realidad del día a día de los marineros. En ella también el protagonista, Christian (interpretado por el actor Clark Gable), se enamora de una de las integrantes de la isla.

Shirley Mangini comenta en su tesis doctoral este ejemplo y, si bien no determina el título de la película a la que alude Marsé, señala que esta forma de narrar resulta muy eficaz para mostrar directamente "el mundo en cierto modo mágico de Manolo, capaz -como Teresa- de vivir la realidad en función de sus más queridos mitos y 'cromos coloreados', determinados en él no por el mundo de la cultura, sino por mitologías más populares" (163-164). Además, indica que si

los sueños de Madame Bovary son productos de las novelas románticas, los de Ana Ozores ( $\mathrm{La}$ Regenta) de ver Don Juan Tenorio y los de Julien Sorel (Le rouge et le noir) inspirados en la revolución francesa, Manolo Reyes se inspira en el cine de Hollywood (1980: 17).

La voz del narrador presenta una simbiosis entre el nombre de la protagonista de esta novela y el apellido de la actriz 'Teresa Simmons' o del nombre de la actriz y el apellido de Teresa, 'Jean Serrat' ${ }^{3}$. No sólo es una asociación entre los nombres de las dos mujeres (Teresa y la actriz), sino también en el hecho de que están bronceadas por el sol, nadan bien, como unas nuevas Venus que parecen ofrecer una imagen publicitaria. Se establece una asociación de objetos, la pelota de playa que lleva en la mano Teresa se convierte en el coco de la isla que fusionan la realidad y el sueño logrando un nuevo cromo de Manolo, una mezcla y un choque entre esa realidad y el deseo. En el cromo, Manolo roza por unos instantes la felicidad, tiene muy cerca su objeto de deseo aunque presagie que se lo van a quitar pronto: "la perderé, no puede ser, no es para mí, la perderé antes de que me deis tiempo a ser un catalán como vosotros”. Es muy importante la referencia a la identidad catalana y a la búsqueda del charnego por integrarse en Cataluña. Este presagio se convierte en realidad al final del libro, momento en el que Manolo busca a Teresa en una moto Ducati robada y la policía lo detiene, encarcelándolo al no tener la documentación.

En los cromos de Manolo se pinta un nuevo mito trágico: la imposibilidad del personaje de alcanzar a su amada, como tantos otros héroes de la literatura anterior. Manolo intenta

portivas (tenis y golf), dos autores preferidos (Blasco Ibáñez y García Lorca), dos películas inolvidables (La isla perdida y Lo que el viento se llevó)" (176). Manuel rellena el impreso al azar y con ironía.

6 Un segundo caso donde Marsé utiliza el recurso de mezclar nombres de los personajes de las novelas con los de películas es en La oscura historia de la prima Montse. La llegada de Paco Bodegas al hogar de Salvador Vilella (casado actualmente con la mujer que amó, su prima Nuria Claramunt) "tuvo algo de clamorosa subida al ring [...], cierto vengativo refinamiento oriental se había ya mezclado con el whisky [...], me habría gustado algo así como verme de pronto vestido de maléfico mandarín chino, convertido en siniestro y sonriente Fu-Manchú rodeado de fieles dakois [...] y poder decir a modo de saludo aquello de: Mi querido Salvador Smith, volvemos a encontrarnos en circunstancias poco favorables para usted" (36). 
conquistar a Teresa por vía del amor, transformándose en lo que ella quiere que sea. Como ha señalado el propio Marsé en una entrevista realizada por Campbell, el Pijoaparte tiene "fe en la escalada social [...] a través del amor" (1971: 197).

Pero esa mascarada se descubre y entonces emerge "el lento deterioro del mito" que, por un lado, muestra el deseo de Teresa de creer que Manolo es un obrero con conciencia social y, por otro, el de Manolo, donde podemos encontrar lo que denominamos el deterioro del mito de El Dorado, es decir, la idea de la lucha continua de algo que se desea con fuerza pero que acaba en frustración y en no obtención de lo deseado.

Dicha idea la observamos en todas las alusiones de Manolo que ven a Teresa como la rubia, la bronceada, la dorada por el sol, a la vez que el acceso a la burguesía es para el Pijoaparte la llegada a la región dorada, representada por la imagen de la isla, un locus amoenus, casi pastoril, el Edén, alejado del tiempo histórico. Pero en Últimas tardes con Teresa el escenario del neoplatonismo renacentista cae en picado: la naturaleza no está en armonía con el hombre, por lo tanto, no puede existir dicha armonía entre el hombre y la mujer, sólo en el pensamiento de cada individuo. Teresa no puede ser para Manolo y viceversa porque sus respectivos estatus sociales están separados por un abismo.

Poco a poco estos cromos abandonan esta escenografía idílica de retirada del mundo a medida que Manolo y Teresa pasan más tiempo juntos. El Pijoaparte trata de ayudar a Teresa en las actividades clandestinas con sus amigos de la universidad y cuando intenta imprimir unos folletos ilegales, acaba malherido, protagonizándose así una de las escenas más melodramáticas entre la pareja. Teresa, al ver a Manolo tendido en el suelo y magullado, se lleva un tremendo disgusto, lo que provoca un derroche de sentimientos:

- ¿Me quieres, Manolo? Júralo.

- Te quiero más que nada en el mundo, te adoro, te necesito.

- [...] Verás lo que vamos a hacer, mi vida: nos ocuparemos de ti, no te preocupes, te ayudaré a encontrar ese empleo que necesitas. No tengo más que hablar con papá, él conoce a mucha gente $[\ldots]$

Teresa se había inclinado y volvía a besarle. Todo el aire estaba impregnado de: anoche hablé con la luna -me dijo tantas cosas- que quizás esta noche- vuelva a hablarte otra vez ... Borrachos de sol y de música, debilitados por la emoción, se dejaron resbalar del todo hasta el suelo y siguieron abrazados mucho rato, como si durmieran [...] Cegada, deslumbrada por una realidad superior, la última sombra querida, el último fantasma huía al fin de aquella cabecita rubia que se frotaba amorosamente contra el pecho del murciano: su tierno y audaz amigo estaba tan solo y perdido como ella (277).

A la escena no le falta ni la música de un bolero romántico que envuelve a Teresa en su particular cromo de equívoco y engaño.

Precisamente ese paisaje idílico de la isla, pero ahora deteriorado, abre La oscura historia de la prima Montse. La vieja casa de la familia burguesa Claramunt va a ser derribada junto con todos sus principios moralizantes católicos que condenaron a Montse a su trágico sino. Una excavadora limpia un pasado que sus miembros quieren borrar, aunque otros, como Paco Bodegas, tratan de rescatarlo y poner las cosas en su sitio. 
La fachada, lo único que queda de la familia Claramunt, oculta la oscura historia de la prima Montse que se suicidó estando embarazada al no poder vivir con Manuel, un charnego sin trabajo del que estaba enamorada. Se trata del mismo Manuel Reyes de Últimas tardes con Teresa ${ }^{7}$, que sigue en su pretensión de escalar socialmente a través de una mujer adinerada y a la que no le importa abandonar a cambio de un puesto de trabajo. Las excavadoras tratan de ocultar un espacio y tiempo antaño idílicos en el que Paco Bodegas y Nuria pasaban muchas tardes juntos y disfrutaban de su amor.

Paco, primo de Montse y ayudante de dirección en París, regresa a Barcelona después de ocho años de la tragedia y narra la oscura historia de su prima Montse: "En algún umbroso y fragante rincón de esta isla hoy yerma, desventrada y maloliente, nació el tierno equívoco, la llama feliz que abrasó a mi prima" (12). Paco se refiere al jardín de los Claramunt y lo compara con el "casco de un barco varado, muerto, recostado sobre la calle e invadido por la arena" (32), espacio que se une a un "tiempo sin orillas" (81). El relato se mueve en dos tiempos, el presente actual desde el que Paco y Nuria Claramunt analizan lo sucedido (1966), intentando en cierto modo modificarlo y, el pasado reciente (1957-1959), que narra la relación entre Manuel y Montse ${ }^{8}$.

Pero Paco no revive sólo la historia de Montse sino también la de su particular aventura con Nuria Claramunt, a la que revela sus fantasías que no quedan tan sólo en la privacidad del personaje:

como una obsesión de Príncipe Valiente, no consigo verte sin un fondo de castillo con torres almenadas y dragón, aquel jardín, aquellas noches estrelladas, un fabuloso decorado siempre unido a ti ... Qué bonito. Había que matar al dragón para merecerte. Y me pregunto si ese telón de fondo, ese dragón que había que vencer y ese castillo, eran un medio o un fin; me pregunto si no me atraía más que tú (137-138).

Nuevamente en esta novela no triunfa el amor entre clases sociales diferentes. Esta vez encontramos a un Manuel más consciente y menos enamoradizo, o con menos fantasías, y a una Montse que sí se atreve a romper con las trabas sociales impuestas por su familia. Recordemos que Teresa no arriesgó al final por Manolo y todo quedó para ella como una aventura de verano.

Veinte años más tarde, su novela El amante bilingüe nos descubre lo que sucedería entre la unión de un personaje charnego, Joan Marés, y una burguesa catalana, Norma Valentí. Aunque llega a consumarse el matrimonio, Norma abandona a Marés y el melodrama surge de los diez años posteriores al divorcio que está Marés intentando ver a Norma, persiguiéndola, buscando su voz y cayendo en un patetismo absoluto, hasta que el personaje decide transformarse en otro, en busca de una identidad que sólo vuelve a encontrar en el barrio que lo vio crecer. Es decir,

$7 \quad$ Al final de La oscura historia de la prima Montse, en el que se describe una fiesta de disfraces que ofrece la familia Claramunt, reaparecen los personajes de Teresa Serrat y Luis Trías entre los miembros de la verbena, que ya habían aparecido en Últimas tardes con Teresa.

8 En Si te dicen que caí Marsé retoma esta estructura para recuperar un pasado desde el presente en que se encuentran los narradores. En La muchacha de las bragas de oro, el personaje de Luys Forest trata de modificar también su pasado. 
lo consigue a través de un desdoblamiento de su personalidad o recurriendo a sus recuerdos infantiles, lo que muestra el difícil acceso a la integración en la sociedad catalana.

\section{El origen de la aventi: Si te dicen que caí}

En el momento de la publicación de Si te dicen que caí (1973), en España todavía se respiraban los coletazos de la censura, así que la obra tuvo que publicarse en México. A este propósito Marsé, escribió una defensa de su novela:

Se trata de una de esas aventis con la que intento ganarme el pan desde que tenía trece años, cuando ya se las contaba a los chicos del barrio oculto tras un antifaz del Coyote, historias inventadas que se nutren de la memoria colectiva y mezclan la verdad verdadera con la mentira mentidera pim pam fuera [...] Un servidor solía pensar en esa aventi [...] como en un tatuaje imborrable o unas cicatrices misteriosas en la maltrecha piel de la memoria [...], una memoria que hay que recuperar y restaurar [...] porque está deteriorada no tanto por el paso del tiempo como por la acción de los hombres desde el poder [...] No renuncio en mis aventis, siempre que haga el caso, a vengarme de un sistema que saqueó y falseó mi niñez y mi adolescencia, el sol de mis esquinas [...]. Y diles a esos timoratos otra cosa que no saben: que detrás del supuesto huracán de intenciones de una novela suele silbar el viento perdido de la infancia común y corriente, sólo eso. Pero que si ellos se empeñan en politizar la cosa, que apechuguen con las consecuencias (1977: 174).

Con Si te dicen que caí aparecen las aventis, que como hemos comentado consisten en aventuras imaginadas por los niños de la posguerra española. Si hasta esta novela los cromos eran fantasías que pertenecían a la mente del personaje y no se compartían con el resto, a partir de esta obra estas imágenes comienzan a narrativizarse, a formar parte de un colectivo, de un auditorio, con posibilidad de intervención y participación de los receptores.

Las aventis constituyen relatos orales mucho más largos que los cromos, que crean una estructura de suspense que puede interrumpirse y luego retomarse. El narrador adulto de esta novela, Antoñito Faneca, es el encargado de definir este nuevo término que se incorpora a la narrativa de Marsé y así se lo transmite a sor Paulina mientras los dos se enfrentan al cuerpo de Java, compañero durante la adolescencia de Antoñito, en una sala de autopsias del hospital en el que trabajan ambos:

un juego bonito y barato que sin duda propició en el barrio la escasez de juguetes, pero que era también un reflejo de la memoria del desastre, un eco apagado del fragor de la batalla [...] Con el tiempo, Java perfeccionó el método: se metió él mismo en las historias y acabó por meternos a nosotros, y entonces el juego era emocionante de veras porque estaba siempre pendiente la posibilidad de que, en el momento menos pensado, cualquiera del corro de oyentes se viera aparecer con una actuación decisiva y sonada [...] Java aumentó el número de personajes reales y redujo cada vez más el de los ficticios, y además introdujo escenarios urbanos de verdad, nuestras calles y nuestras azoteas y nuestros refugios y cloacas, y sucesos que traían los periódicos y 
hasta los misteriosos rumores que circulaban en el barrio sobre denuncias y registros, detenidos y desaparecidos y fusilados. Era una voz impostada recreando intrigas que todos conocíamos a medias o de oídas: hablar de oídas, eso era contar aventis, Hermana. Las mejores eran aquellas que no tenían ni pies ni cabeza pero que, a pesar de ello, resultaban creíbles: nada por aquel entonces tenía sentido, Hermana, ¿se acuerda?, todo estaba patas arriba, cada hogar era un drama y había un misterio en cada esquina y la vida no valía un pito, por menos de nada Fu-Manchú te arrojaba al foso de los cocodrilos (28-29).

En esta cita inicial, Antoñito Faneca nos presenta las pautas que sigue la aventi: a) una escenografía que ya no es un locus amoenus, como en los cromos imaginados de Manolo el Pijoaparte, sino una ciudad 'de cartón piedra' (7), llena de escombros, corrupción, miseria, bombas; b) unos personajes - normalmente niños o adolescentes- que forman parte de la realidad en la que se vive y que pueden implicarse en la historia narrada, por lo tanto, la aventi siempre conlleva un poso de verdad que cuestiona las fronteras entre la apariencia y la realidad; c) un relato que se compone de un collage de fragmentos de conversaciones, de noticias de periódicos y de películas, como ya delata la cita a Fu-Manchú, relato que no sólo es narración sino también representación, 'era una voz impostada'; d) unos fines concretos de los personajes: matar el aburrimiento, la pobreza de la posguerra; realizar una crítica social ante la represión, aquí la figura aludida de Fu-Manchú encubre a la del dictador Francisco Franco y e) aunque en la cita no se recoja, encontramos que las aventis se construyen a partir de hechos pasados pero también venideros: "este chico cuenta aventis basándose no sólo en los sangrientos hechos pasados sino también en los hechos por venir" (110). En consecuencia, las aventis se aproximan a las anécdotas orales con unos receptores que marcan en todo momento el interés por lo que se narra con elementos como "cuenta", "sigue", etc.

Algunos críticos han abordado una definición de este concepto. Así, José Ortega (1976) enmarca la aventi

dentro de la teoría poética que exige lo verosímil y lo maravilloso [...], es lo poético compensando la realidad degradada [...]. Esta interacción de verdad y realidad que presenta la aventis se realiza de forma breve quizá para que el auditorio tenga tiempo para reflexionar sobre su verdad y para que el interés no decaiga [...]. La fantasía de las aventis se funda en el desquizamiento de la posguerra, en la ruptura de todo tipo de orden [...], fundamenta la fábula, pues sin la peripecia del aventis no hay historia (736-737).

Además, para este mismo autor, el intento de evadirse de lo amargo que resulta lo cotidiano puede explicar "la importancia concedida por estos jóvenes al mundo del cine, fantasioso orbe que se compara al de las aventis" (737).

Shirley Mangini subraya la creación de la aventi como un procedimiento narrativo dado por una visión dual (la del niño y la del adulto) que muestra

su aguda conciencia frente a la transformación dialéctica de verdad y mentira en una realidad 'real', [...] nos presenta una ficción dentro de otra, evocando así todas las posibles ambigüedades que están implicadas en una realidad sumamente proteica (1979: 7). 
Por su parte, Manuel Ríos define la aventi como una interpretación o recomposición de lo que podrían ser o haber sido las cosas que se contemplan a medias "como tras la figura de un tabique" (73). Asimismo, Balbina Samaniego (1996) explica en un artículo el concepto de aventi clasificándola, por un lado, como juego (la aventi se forma de la contracción de palabras 'aventura inventada' y es una mezcla de películas que han visto los niños, de tebeos o novelas que han leído, o historias que han oído) y, por otro lado, como técnica narrativa fundada por tres parámetros: la historia, que reconstruye la memoria colectiva, la fantasía y la censura9 .

Son varios los relatos que se intercalan en Si te dicen que caí y que están unidos a los principales temas que utiliza Marsé en sus novelas. En cada uno se utilizan elementos cinematográficos. Así, el de la prostituta roja, Aurora/Ramona, se conecta con el tema del doble, pues no llegamos a saber de quién se trata, ya que para más inri se mezclan los nombres de Carmen y Menchu, una prostituta de lujo que no se termina de discernir si se trata de la misma. Es la más buscada desde todos los frentes: el de los vencedores y el de los vencidos en la guerra.

Otro de los relatos está representado por Conrado Galán y su madre, quienes buscan a Aurora para ajustar cuentas con el pasado. Recordemos que ante la perversión de Conrado de vigilar a Aurora y su novio Marcos Javaloyes mientras tienen sexo, los maquis y el tío de la chica, Artemio Nin, se vengan de Galán pero asesinando al padre de éste. Tiempo después, Ramona/ Aurora está en una matinal del cine Roxy, junto a Java, interesado también en la chica por la información que pueda obtener de ella para la señora Galán a cambio de dinero. Se describe lo que ven en la pantalla:

Arsenio Lupin manejando una linterna eléctrica en el salón oscuro de una lujosa mansión: guantes blancos, pañuelo de seda al cuello, chistera ladeada sobre una ceja. [...] En la pantalla unos chillidos de mujer, los faros de un automóvil en la noche, parado en la carretera, y un hombre asustado debatiéndose entre sus dos verdugos que lo sujetaban; un tercero sacando la pistola del bolsillo y la mujer chillando no le matéis, ése no es Arsenio Lupin, no le matéis. Y los tiros, dos, tres, cuatro y el pecho agitado de Ramona bajo su mano encendida, el corazón de la pajillera ahora retumbando. ¿Qué te pasa mujer?, no es más que una peli, y sus manos repentinamente en la cara tapándose los ojos para no ver. Ya pasó todo, dijo él sonriendo, ¿no te gustan las de intriga?, pero ella siguió un buen rato ocultando la cara en las manos temblando (138 y 140) ${ }^{10}$.

Para Java estas imágenes carecen de sentido y sólo puede llegar a pensar que Ramona tiene miedo de la película, pero el lector sabe que lo que realmente provoca ese sentimiento en la chica es el recuerdo de cómo su tío mató al padre de Conrado por equivocación. También fue un tiroteo en donde Aurora trató de subsanar el error, pero no le hicieron ningún caso.

En el otro bando, los niños soportan la miseria de la posguerra creando aventis sobre la prostituta roja. Java comienza una serie de interrogatorios entre la gente del barrio que se desarrollan a lo largo de la novela. Contratado por la señora Galán, se convertirá en un detective parecido a muchos de los que ha visto en la oscuridad de las salas de cine. Primero, pregunta

9 Otros autores llevan más allá el significado del término, así para Nivia Montenegro la palabra aventi está "relacionada con el verbo aventar -cuyo significado primero es hacer o echar aire a alguna cosa- indica la característica esencial de las historias: inflación o deformación de la realidad" (155).

10 Se alude a la película de J. Conmway (1932). Arsène Lupin, adaptación de la novela del escritor M. Leblanc. 
a las huérfanas de la casa de las Ánimas, Juanita la Trigo y la Fueguiña; a la dueña de la casa de citas y a Balbina, una de las prostitutas compañera de Ramona. A partir de los testimonios de estas mujeres conocemos parte de la historia de Aurora: cómo Conrado Galán la espiaba a ella y a su novio republicano Pedro mientras hacían el amor.

La pretensión de Java, al igual que la de Manolo Reyes, es ascender socialmente y salir del barrio. En sus aventis sigue las pautas del cine negro: se basa en el engaño de las apariencias, la doblez y la ocultación, se privilegia la mirada y encontramos una narración fragmentada, no lineal, con muchos saltos espaciales y temporales.

Al mismo tiempo, Sarnita sigue muchas veces a su amigo Java para descubrir la causa del interés por esta mujer, "parecía jugar a detectives" (55) y va a ser el gran recreador de los hechos. Por ejemplo, Conrado ensaya una obra de teatro y Sarnita lo imita cogiendo a María la Fueguiña como actriz:

- Tú vas vestida de hombre, con la túnica y el cinturón de oro de San Miguel, con la capa, la espada y el casco. Pero figura que eres un chico, ¿entiendes? Quiero decir que eres una chica de verdad, pero te haces pasar por hombre. Y nosotros no lo sabemos.

- Y éste lucha contigo y os caéis al suelo, y entonces pierdes el casco y se te sueltan los cabellos largos de chica, así, mira, como en La Corona de Hierro, ¿la has visto?

- No.

- ¿Y La Prisionera Desnuda, la has visto, niña?

- Tampoco. Amén dice que tus películas son mentira.

- ¿Cómo?

- Sí. Que las películas que cuentas no existen, nadie las ha visto nunca. Que tú te inventas esas pelis, Sarnita.

- Amén tiene una gotera en el coco, chavala. ¿Y Suez, la has visto?

- ¿Suez?

- Sí. Todo el mundo la ha visto. Tú eras Anabella y éste era Tyrone Power, ¿vale? Hay un ciclón sobre el desierto y tú salvas a éste atándolo a un poste, mira, aquí tienes la cuerda. Entonces figura que el ciclón te empieza a arrastrar, él se ha desmayado y se despierta atado al poste y ve que estás perdida, y te aprieta entre tus brazos porque además está enamorado de ti, pero el viento es muy fuerte y todo es inútil [...]

- No -dijo María-. No me gusta el cine, casi nunca voy (179-180).

Sarnita toma de las películas no sólo argumentos, sino también gestos o movimientos estereotipados para después repetirlos, o incluso recoge momentos míticos de un texto fílmico que para él han quedado grabados en su memoria. Tanto La corona de hierro como Suez ${ }^{11}$ se consideran dos películas de éxito en la época, en cambio, La prisionera desnuda pertenece al inventario fílmico de Sarnita, como posible título a la película que él dirigiría.

La historia de esta prostituta es paralela a la de otra mujer que aparece en la novela, que se conoce también por dos nombres distintos: Carmen y Menchu, a la que se la distingue por un brazalete de escorpión que lleva siempre. En este relato intervienen los maquis que quedan

11 A. Blasetti (1941). La corona di fierro [La corona de hierro] y A. Dwan (1938). Suez. 
después de la guerra, grupo formado por el Taylor, Palau, Jaime Viñas, Luis Lage, Bundó, Marcos Javaloyes, Sendra, el Fusam, Navarro, Guillén, a los que se llega a ridiculizar ya que para conseguir dinero incurren a las fechorías más bajas (atracadores de bancos, estafadores, asesinos, etc.).

Como ya señala Nivia Montenegro, el proceso que sufre el grupo se resume en la metáfora que los presenta, y cita la frase de "hombres de hierro, forjados en tantas batallas, llorando más tarde por los rincones de las tabernas como niños" (149) y, que al concluir la novela, se repite como: hombres de hierro, forjados en tantas batallas, soñando como niños (277) donde "el intenso dolor que sienten al terminar la guerra se transforma con el paso del tiempo en una cínica adaptación, para terminar, treinta años después, en una recolección nostálgica”. Recordemos a uno de los miembros de esta banda, Lage, que se presenta siempre con una violenta obsesión por las armas y que al final del libro se describe cómo "Lage apretaba al costado una sobada cartera de piel marrón, esgrimía en la otra mano el paraguas cerrado y con la contera trazaba líneas en el suelo mojado" (274).

En su tesis doctoral, Kirsch ha subrayado también la teatralidad de las escenas en las que intervienen los maquis:

Estos atracos, asesinatos y corridas de coche se parecen sobre todo a lo retratado en las películas de gángsters. Esto se observa especialmente en la escena del robo armado del Hotel Ritz, episodio en que los maquis van entrando simultáneamente en las habitaciones de los huéspedes. Aún hay cierto manierismo aquí, pues, antes de escaparse con los bienes robados, uno de los maquis se detiene para colocar una gardenia en el ojal. Así, no sólo coincide la técnica en algún momento con técnicas cinematográficas, sino que el cine habrá influenciado los episodios mismos de la novela (202).

Por lo tanto, la Historia se mezcla con las historias o aventis que se cuentan en esta novela, dando lugar a una mezcla entre apariencia y realidad muchas veces difícil de discernir pero de gran ayuda para la supervivencia de los personajes en la posguerra española.

\section{Conclusiones}

Las palabras del propio Juan Marsé, en las que concibe la creación de sus novelas a partir de imágenes, nos llevan a comprobar el modo en que se traduce esta concepción poética en obras concretas como Últimas tardes con Teresa o La oscura historia de la prima Montse. En ellas, las imágenes son todavía cromos o pequeñas postales que pertenecen a la intimidad de los personajes, que poseen un fuerte tono melodramático e idílico y que se corresponden, fundamentalmente, con un deseo de ascenso social en la burguesía catalana por parte del protagonista masculino. Los personajes femeninos también recrean estos cromos pero sin ninguna aspiración social o identitaria, sino con el deseo de cambiar la realidad a su gusto de manera momentánea.

Con la publicación de Si te dicen que caí estas imágenes cobran mayor autonomía y se convierten en aventis, es decir, en aventuras orales que mezclan la realidad con lo escuchado de oí- 
das o con lo visto en las salas de cine de barrio. Sin dejar de lado el componente melodramático, se enriquecen con otros elementos que recuerdan al cine negro y del oeste de los años 30 y 40.

Estas aventis dan un paso más respecto a la recreación de historias en los cromos anteriores, ya que no pertenecen a la privacidad de sus protagonistas sino que se comparten oralmente ante un auditorio, consiguiendo tal visualidad que los lectores llegamos a ser espectadores de esta narrativa. Además, en ellas se acentúa la crítica social.

Tanto cromos como aventis tienen en común el hecho de ser una forma de evasión de la realidad que les ha tocado vivir a los personajes.

\section{Referencias bibliográficas:}

\section{Fuentes primarias:}

Marsé, J. (1970/1978). La oscura historia de la prima Montse (4ª reimpresión). Barcelona: Seix Barral.

- (1977). La aventi secuestrada (Carta de Sarnita al chorizo). In Confidencias de un chorizo. Barcelona: Planeta.

_. (1981). Últimas tardes con Teresa ( $8^{\mathrm{a}}$ ed.). Barcelona: Seix Barral.

. (1990). Primera imagen, primer latido. El Sol, 5 de octubre de 1990.

. (1993). Si te dicen que caí (3a ed.). Barcelona: Seix Barral.

\section{Fuentes secundarias:}

Amell, S. (1982). La novela española actual. Un representante: Juan Marsé. Tesis doctoral. Albany: State University of New York.

- (1984). La narrativa de Juan Marsé. Madrid: Playor.

Bellón Aguilera, J. L. (2009). La mirada pijoapartesca (Lecturas de Marsé). Ostrava: Ostravská univerzita v Ostravě.

Bonet, L. (2009). Juan Marsé en sus "verdades verdaderas" (I parte). Ínsula. Revista de Letras y Ciencias Humanas, 755.

_ (2010). Juan Marsé en sus “verdades verdaderas" (II parte). Ínsula. Revista de Letras y Ciencias humanas, 759.

Campbell, F. (1971). Juan Marsé o el escepticismo. Infame turba (pp. 218-227). Barcelona: Lumen.

Castellani, J. P. (2003). Lectures d’une oeuvre El embrujo de Shanghai. Juan Marsé/Fernando Trueba. Nantes: Éditions du Temps.

Cuenca, J. Ma. (2015). Mientras llega la felicidad. Barcelona: Anagrama.

Freixas, R. (1984). Hipnotizar por la imagen. Quimera, 41, septiembre, 50-55.

Kim, K. L. (2006). El cine y la novelística de Juan Marsé. Madrid: Biblioteca Nueva.

Kirsch, J. A. (1980). Técnica novelística en la obra de Juan Marsé. Tesis Doctoral. Madison: Universidad de Wisconsin.

López de Abiada, J. (2002). Nuevas tardes con Marsé. Murcia: Nausicaä.

Mangini González, S. (1979). El punto de vista dual en tres novelistas españoles. Ínsula, 396-397, 7-9.

- (1980). Últimas tardes con Teresa: culminación y destrucción del realismo social en la novelística española. ANEC, 5, 13-26. 
Marí, J. (2003). Lecturas espectaculares. El cine en la novela española desde 1970. Madrid: Ediciones Libertarias.

Moix, A. Ma . (1973). Juan Marsé. $24 x 24$ (entrevistas) (pp. 119-127). Barcelona: Ediciones Península.

Montenegro, N. (1981). El juego intertextual de Si te dicen que caí. Revista Canadiense de Estudios Hispáni$\cos , 5(2), 145-155$.

Ortega, J. (1976). Los demonios históricos de Marsé: Si te dicen que caí. Cuadernos Hispanoamericanos, $312,731-738$.

Peña-Ardid, C. (2002). Intertextualidad e intermedialidad. Pensar el cine desde la novela. In C. F. Heredero (Coord.), La imprenta dinámica. Literatura española en el cine español (pp. 447-470). Cuadernos de la Academia (11/12): Academia de las Artes y las Ciencias Cinematográficas de España.

Ríos, M. (1981). Los aventis de Juan Marsé, el novelista de nuestro tiempo. Nueva Estafeta, 27, febrero, $71-74$

Roig, M. (1975). Juan Marsé o la memoria enterrada. Los hechiceros de la palabra (pp. 84-91). Barcelona: Martínez Roca.

Rodríguez Fischer, A. (2008). Ronda Marsé. Barcelona: Candaya Ensayo.

Romea Castro, C. (2005). Juan Marsé, su obra literaria. Lectura, recepción y posibilidades didácticas. Barcelona: Horsori.

Samaniego, B. (1993). Entrevista con Juan Marsé. Anales de la Literatura Española Contemporánea, 18 (2), 375-388.

— (1996). La aventi marseniana: juguete y látigo. Alba de América. Revista Literaria, 14, julio, 437443.

Seguin, J.C. (2004). Shanghai, entre promesse et sortilège. Lyon: Le Grimh/LCE-Grimia. 